\title{
Expression of Microsatellite Instability (MSI) from Colorectal Carcinoma Patients
}

\author{
Jae Sik Lee \\ Department of Clinical Laboratory Science, Hyejeon College, Hongseong 350-702, Korea
}

\begin{abstract}
The death toll of Colorectal Carcinoma in Korea was 1,826 and 7,721 in the years 1992 and 2011, respectively. This rate of increase was shown to be more than 4.23 times higher than that of any other form of cancer. Therefore, Colorectal Carcinoma requires various diagnostic methods, and Microsatellite Instability (MSI) was applied as a new diagnostic tool. From this study with several microsatellite markers, only marker \#13 was detected and observed D13S160 13\% (4/30), D13S292 13\% (4/30), D13S153 10\% (3/30) in order. From the results of amplication with microsatellite marker, D13S292 37\% (11/30), D13S153 33\% (10/30), D13S160 33\% (10/30) in order were shown. The appearance of a genetic mutation, which depends on the loci of Colorectal Carcinoma, was shown amplication from rectal cancer (3.77) which was higher than that of right Colorectal Carcinoma (2.08) $(p<0.018)$. The genetic mutation with lymph node (4.13) appeared higher than normal (1.93) $(p<0.001)$. There were no great differences in the genetic mutation dependent on disease, histological classification and increased group of serum CEA. Accordingly, it is suggested that the correct primers, which can evaluate MSI well from colorectal carcinoma, should be chosen and that MSI be considered a good prognosis and quality control tool.
\end{abstract}

Keywords: Microsatellite Instability (MSI), Colorectal carcinoma, Amplification, Microsatellite marker

This is an Open Access article distributed under the terms of the Creative Commons Attribution Non-Commercial License (http://creativecommons.org/licenses/by-nc/3.0) which permits unrestricted non-commercial use, distribution, and reproduction in any medium, provided the original work is properly cited.

Copyright @ 2014 The Korean Society for Clinical Laboratory Science. All rights reserved.
Corresponding author: Jae Sik Lee Department of Clinical Laboratory Science, Hyejeon College, Hongseong 350-702, Korea Tel: 82-41-630-5340 E-mail: jslee@hj.ac.kr

Received: May 19, 2014 Revised: June 17, 2014 Accepted: June 22, 2014

\section{Introduction}

The occurrence rate of colorectal carcinoma shows high from North America, Europe and Australia and low from Asia, South America and Africa. The death toll of colorectal carcinoma in Korea was 1,826 and 7,721 in the year of 1992 and 2011, respectively. This rate of increase was shown more 4.23 times highly than that of any cancer (National Statistical Office of Korea, 1992-2011).

The primary reason on the increased death rate from colorectal carcinoma was caused by the overindulgence of animal fats and saturated fatty acids from the Westernized eating habits and little physical activity from changed life style, which are caused for increase of colorectal carcinoma (Shin et al., 2013).
It was reported that the occurrence rate of colorectal carcinoma from Asian countries including Korea shows low but became high since the Westernized life style was flourished in 1990 after. The people who had been lived in the Japan and South America, showing low occurrence rate of colorectral carcinoma had been moved the USA and Canada which have the high rate of colorectal carcinoma. However, there are high level of occurrence rate in the moved countries (Juon et al., 2003).

Generally the under-methylation of DNA were found from the tissue of colorectal carcinoma patients and the unstable over-methylation were shown in the part of $\mathrm{CpG}$ dinucleotide. The normal expression of methyltransferase mRNA increased more 60 200 times higher than that of colon polyp and colorectral carcinoma. 
To find the cause of occurrence about colorectal carcinoma with molecular tools, there are PCR products with microsatellite markers from under-methylated and unstable methylated part.

The primary reason on microsatellite instability (MSI) is happened that DNA mismatch gene was caused when the error could not proofread during DNA replication processing. Several genes were known for hMSH2, hMLH1, hPMS1 and hPMS2 as mismatch repair genes. The study of correlation between MSI and cancer was reported from hereditary non-polyposis colorectal cancer (HNPCC) by Aaltonen in the year of 1993. After this, several researches were found from other cancer as well as colorectal carcinoma (Macdonald et al., 1998; Yamamoto et al., 1999).

In this study, to find instability of methylation from Korean colorectal carcinoma, the location of microsatellite instability and under-methylation with microsatellite marker was compared with several reports from foreign countries. With those results, it is expected that the microsatellite marker as diagnostic technique can be applied in clinical field which is the pivotal role such as gene locus, treatment and prognosis to know the carcinogenesis of colorectal carcinoma.

\section{Materials and Methods}

\section{Materials}

To analyze microsatellite instability, the tissues of thirty colorectal carcinoma patients who was operated in one hospital in Busan were used for this study. The extracted DNA from tumor and normal tissue was used for microsatellite instability analysis and described the clinical situation of each patient (Table 1).

The subjects consist of fourteen men and sixteen women with 55 (32 80) as an average age. The clinical stages were two patients of stage I, ten of stage II, fifteen of stage III and three of stage IV, which are based on criteria of American Joint Committee on Cancer (AJCC). The histological types consist of 17 of well differentiated, 8 of moderately differentiated, 3 of poorly differentiated and 2 of mucinous carcinoma.

\section{DNA extraction}

After cut of tumor and normal tissue, DNA was extracted using a genomic DNA purification kit (Promega, USA). Add nuclei lysis solution and $10 \mathrm{mg} / \mathrm{mL}$ of proteinase $\mathrm{K}$ into tissue and place it at 55C incubator to dissolve the tissue completely. RNA was removed with RNAse and protein was precipitated in protein precipitation solution. After transfer the supernatant, gently wash with serial ethanol. Finally, DNA was extracted with DNA rehydration solution. The final concentration of DNA was adjusted with $0.1 \sim 0.9 \mu \mathrm{g} / \mathrm{mL}$ and was finally chosen with the ratio, $1.6 \sim 1.8$.

\section{Synthesis of Microsatellite oligonucleotide primer}

The verified base sequence for primers of cytogenetic localization was found from Genbank of ncbi.nlm.nih.gov and other references. The primers with long and stable sequence, considering for the secondary structure after PCR were designed. The designed and synthesized primers were prepared by (GenoTech, Korea).

\section{Method}

1) Microsatellite amplification by $P C R$

Dilute DNA to be template bring to $50 \mathrm{ng} / \mu \mathrm{L}$ with TE buffer

Table 1. Mean number of microsatellite instability of events per tumor in colorectal carcinoma according to the location, the level of serum CEA, histological type and stage

\begin{tabular}{lcc}
\hline Variables & Cases & Microsatellite Instability \\
\hline Location & & \\
Right colon & 12 & 2.08 \\
Rectum & 18 & 3.77 \\
$\quad p$-value & & 0.018 \\
Serum CEA & \\
$\leq 5$ (ng/mL) & 16 & 2.94 \\
$>5$ (ng/mL) & 14 & 3.29 \\
$\quad p$-value & & 0.638 \\
Differentiation & & \\
Well & 17 & 2.71 \\
Moderate to poor & 13 & 3.62 \\
$\quad p$-value & & 0.216 \\
Lymph node & & \\
Negative & 14 & 1.93 \\
N1-3 & 16 & 4.13 \\
$p$-value & & 0.001 \\
Stage & & 2.25 \\
I-II & 12 & 3.67 \\
III-IV & 18 & 0.098 \\
$p$-value & & \\
Total & 30 & \\
\hline
\end{tabular}


and PCR was performed: DNA $100 \mathrm{ng}, 10 \mathrm{pmol}$ of forward and reverse primer, with the thermocycling conditions set at $94^{\circ} \mathrm{C}$ for $5 \mathrm{~min}$, followed by 30 cycles of 94 for $30 \mathrm{~s}, 72^{\circ} \mathrm{C}$ for $30 \mathrm{~s}$, and $72^{\circ} \mathrm{C}$ for $5 \mathrm{~min}$. PCR was performed 3 times for each primer to get reproducibility and get clear bands under $2 \%$ agar gel.

\section{2) DNA sequencing gel and electorphoresis}

DNA sequencing gel was acrylamide/bis-acrylamide, urea (Sigma, USA), with $5 \times \mathrm{TBE}$ buffer bringing to $6 \%$ polyacrylamide gel with the gel plate of $33 \mathrm{~cm} \times 40 \mathrm{~cm} \times 4 \mathrm{~mm}$ and electrophorized with Model S2 sequencing gel eletrophoresis apparatus (Life Technologies, USA) and prerunned for 1 hour.

Denaturated for $5 \mathrm{~min}$ at $94^{\circ} \mathrm{C}$ with the ratio $2: 1, \mathrm{PCR}$ product to loading solution $95 \%$ formamide, $10 \mathrm{mM} \mathrm{NaOH}$, bromphenol blue, xylene blue), respectively. After a rapid cooling on ice and loaded with 1,500 V for 3 hours.

\section{3) Silver staining and Interpretation}

After electrophoresis, gel was stained with silver staining kit (Bioneer, Korea) and applied onto fixing, enhancing, staining and developing. Followed by these four steps, gel plate was dried and saved the image by computer scanner.

Amplification was decided when an allele from tumor cells increase more $50 \%$ than that of normal cell after measurement of density on each band.

\section{Statical Analysis}

The correlation from the number of changed gene, locus of colorectal carcinoma, histological distribution, lymph node spread, kind of disease, increase of serum CEA was compared and verified by SPSS program and considered significant when the $p$-value was less than 0.05 .

\section{Results}

\section{Detection of Microsatellite Instability (MSI)}

Specifically only No. 13 marker was detected and observed D13S160 13\% (4/30), D13S292 13\% (4/30), D13S153 10\% (3/30) in order when microsatellite instability (MSI) was compared depends on each microsatellite marker.

\section{Detection of Amplification}

From the results of amplication with microsatellite marker, D13S292 37\% (11/30), D13S153 33\% (10/30), D13S160 33\% $(10 / 30)$ in order were shown.

\section{Colorectal carcinoma location, level of serum CEA, histological type and stage}

The appearance of genetic mutation depends on the loci of colorectal carcinoma was shown amplication from rectal cancer 3.77 was higher than that of right colorectal carcinoma 2.08. The genetic mutation with lymph node 4.13 was appeared higher than normal $1.93(p<0.001)$. There were no great difference from genetic mutation depends on disease, histological classification and increased group of

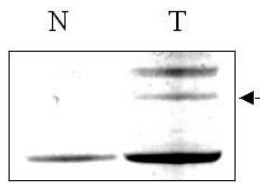

D 13 S $153($ Pt 20)

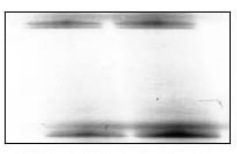

D) $13 \$ 153($ Pt 16)

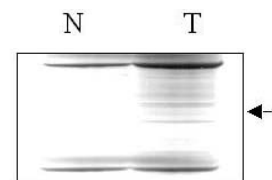

D13S160 (Pt 18)

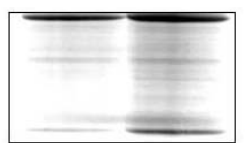

D13S160 (Pt 6)

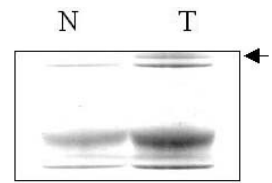

D13S292 (Pt 23)

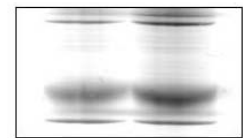

D13\$292 (Pt 22)
Fig. 1. Microsatellite Instability and Amplification at various chromosome in colorectal carcinoma by silver stain. $\mathrm{N}$, normal tissue; T, tumor tissue.

Table 2. Primer sequence of the microsatellite markers

\begin{tabular}{cclc}
\hline Name & Cytogenetic localization & \multicolumn{1}{c}{ Primer sequence } & Annealing temp $\left({ }^{\circ} \mathrm{C}\right)$ \\
\hline D13S153 & $13 q$ & $5^{\prime}-$ GTTTCATGTTGGTGTACGTC-3' & 53 \\
& & $5^{\prime}-$ TTGTGGAAAGGAGCGTATCT-3' & 55 \\
D13S160 & 13q21-13q31 & $5^{\prime}-$ CGGGTGATCTAAGGCTTCTA-3' & 56 \\
& & $5^{\prime}-$ GGCAGAGATATGAGGCAAAA-3' & 56 \\
\hline
\end{tabular}


serum CEA (Table 1).

\section{Discussion}

Colorectal carcinoma is considered as serious one of solid cancers which needs a central control. This colorectal carcinoma is specifically not occurred onto only Westerners but can be onto Korean. Therefore, the study should be performed about the genetic features of Korean based on reported data of foreigners.

It requires enormous efforts that the gene related with the occurrence and development of colorectal carcinoma should be found, which are helpful on diagnosis and treatment. These trails are currently on the way from several institutes (Juon et al., 2003; Sunde et al., 2009; Shin et al., 2013).

The principle of molecular and genetical methods use microsatellites have diversity and polymorphic features, distributes on chromosomes of human genome. In other words, the repeated base sequences are applied with markers on chromosome loci. With tumor and normal DNA, they are amplified with PCR, electrophoresis on sequencing gel, evaluate the ratio of density and finally copied number of tumor genes (Bocker et al., 1997).

The features of this study are 13q amplification and MSI, which are consistent with those of previous studies such as a frequent MSI on 13th chromosome of colorectal carcinoma. It is suggest that this locus of 13th chromosome has high possible gene related with cancer development and progress when the 13th chromosome locus shows MSI (Trautmann et al., 2006).

The cancer-related gene on 13q are BRCA2, on 13q12, RB1 on 13q34 and DP1 on 13q34. DP1 was known for activation by D1 cyclin and CKD during the cell cycling, G1 to S1 and also has a crucial role on the progress of cell cycle with transcription of various genes. Especially, it was reported that this gene make squamous epithelium cell of esphageal cancer amplification. The another possible gene can be FLT1 but there are no clear proof but it is supposed that this FLT1 can be related with angiogenesis normally or abnormally (Gerber et al., 1997).

It was reported that 13q amplification from tumor shown 4 times higher than that of adenoma and $2 \sim 3$ times higher in metastasized cancer than in early cancer. This study was shown that the detection rate appeared 100\% from colorectal carcinoma patient among total 37\% detection rate. D13S292 on BRCA2, D13S153 and D13S160 on RB1 were chosen and found $100 \%$ amplification to confirm and compare. Despite of limited MSI on 13q, it is suggested that the high detection rate of MSI showed $67 \%$ in the metastasized liver cancer. This means that MSI can be played a crucial role from metastasized cancer (Ried et al., 1996; Parede et al., 1998; Xie et al., 2007).

In this study, Microsatellite instability (MSI) was found in the only $13 q$ locus by $10-13 \%$, which are significant results, comparing with $9.5 \%$ from Germany, $10.7 \%$ from Brazil, 13.8\% from Tunisia, $14.2 \%$ from Denmark and 20.6\% from USA. Comparative difference depends on races and nations were shown (Trautmann et al., 2006; Sunde et al., 2009; Campanella et al., 2013; Hoffmeister et al., 2013; Je et al., 2013; Ziadi et al., 2014).

The relative high detection rate of MSI was reported from few countries. It is suggested that this is not caused by tumor's features but by the instability of primers. To prevent this phenomenon, the program was already developed so the secondary structure of PCR product as primer sequence should be confirmed. But for primers, the primer sequence toward 3 primer is preferred. Primers have high content of $G$, $\mathrm{C}$ and low of $\mathrm{A}, \mathrm{T}$ can be produced low number of products and lots of dimers, thereby the false MSI can be prevented. An not-appropriate temperature can be brought subbands of PCR products so the best PCR condition will be necessary to detect clear band.

MSI appears on other solid cancer as well as colorectal carcinoma as $18 \%$ on 3 rd chromosome of lung cancer, $13 \%$ on 12 th chromosome of uterine cancer, $1.5 \%$ on 11 th chromosome of prostate cancer. Therefore, MSI can be valuable examples to diagnosis on colorectal carcinoma as well as other solid cancer (Castagnaro et al., 2007; Schwarzenbach et al., 2008; Murayama et al., 2010).

In conclusion, MSI means that the deletion and insertion of repeated chromosome unit from tumor tissues make a change of microsatellite length. This MSI can be suggested as a new diagnosis tool for colorectal carcinoma (Campanella et al., 
2013). Accordingly, it is suggested that the correct primers which can be evaluate MSI well from colorectal carcinoma should be chosen and this MSI will be expected the good prognosis tool with quality control.

\section{Acknowledgements: None \\ Funding: None \\ Conflict of interest: None}

\section{References}

1. Bocker T, Diermann J, Friedl W, Gebert J, Holinski-Feder E, Karner-Hanusch J, et al. Microsatellite instability analysis: a multicenter study for reliability and quality control. Cancer Res. 1997, 57:4739-4743.

2. Campanella NC, Berardinelli GN, Scapulatempo-Neto C, Viana D, Palmero EI, Pereira R, et al. Optimization of a pentaplex panel for MSI analysis without control DNA in a Brazilian population: correlation with ancestry markers. Eur J Hum Genet. 2013, 256:1038-1045.

3. Castagnaro A, Marangio E, Verduri A, Chetta A, D'Ippolito R, Del Donno M, et al. Microsatellite analysis of induced sputum DNA in patients with lung cancer in heavy smokers and in healthy subjects. Exp Lung Res. 2007, 33:289-301.

4. Gerber HP, Condorelli F, Park J, Ferrara N. Differential transcriptional regulation of the two vascular endothelial growth factor receptor genes. Flt-1, but not Flk-1/KDR, is up-regulated by hypoxia. J Biol Chem. 1997, 272:23659-23667.

5. Hoffmeister M, Bläker H, Kloor M, Roth W, Toth C, Herpel E, et al. Body Mass Index and Microsatellite Instability in Colorectal Cancer: A Population-based Study. Cancer Epidemiol Biomarkers Prev. 2013, 22:2303-2311.

6. Je EM, Gwak M, Oh H, Choi MR, Choi YJ, Lee SH, et al. Frameshift mutations of axon guidance genes ROBO1 and $\mathrm{ROBO} 2$ in gastric and colorectal cancers with microsatellite instability. Pathology. 2013, 45:645-650.

7. Juon HS, Han W, Shin H, Kim KB, Kim MT. Predictors of older Korean Americans' participation in colorectal cancer screening. J Cancer Educ. 2003, 18:37-42.

8. Macdonald GA, Greenson JK, Saito K, Cherian SP, Appelman $\mathrm{HD}$, Boland CR. Microsatellite instability and loss of hetero- zygosity at DNA mismatch repair gene loci occurs during hepatic carcinogenesis. Hepatology. 1998, 28:90-97.

9. Murayama-Hosokawa S, Oda K, Nakagawa S, Ishikawa S, Yamamoto S, Shoji K, et al. Genome-wide single-nucleotide polymorphism arrays in endometrial carcinomas associate extensive chromosomal instability with poor prognosis and unveil frequent chromosomal imbalances involved in the PI3-kinase pathway. Oncogene. 2010, 29:1897-1908.

10. Paredes-Zaglul A1, Kang JJ, Essig YP, Mao W, Irby R, Wloch M, et al. Analysis of colorectal cancer by comparative genomic hybridization: evidence for induction of the metastatic phenotype by loss of tumor suppressor genes. Clin Cancer Res. 1998, 4:879-886.

11. Ried T, Knutzen R, Steinbeck R, Blegen H, Schröck E, Heselmeyer K, et al. Comparative genomic hybridization reveals a specific pattern of chromosomal gains and losses during the genesis of colorectal tumors. Genes Chromosomes Cancer. 1996, 15:234-245.

12. Schwarzenbach H, Chun FK, Müller I, Seidel C, Urban K, Erbersdobler A, et al. Microsatellite analysis of allelic imbalance in tumour and blood from patients with prostate cancer. BJU Int. 2008, 102:253-258.

13. Shin Al, Jung KW, Won YJ. Colorectal cancer mortality in Hong Kong of China, Japan, South Korea, and Singapore. World J Gastroenterol. 2013, 19:979-983.

14. Sunde L, Bisgaard ML, Soll-Johanning H, Jacobsen NO, Bolund L, Skouv J, et al. Familial colorectal cancer, can it be identified by microsatellite instability and chromosomal instability? - A case-control study. Cancer Biomark. 2009, 5:197-205.

15. Trautmann K, Terdiman JP, French AJ, Roydasgupta R, Sein N, Kakar S, et al. Chromosomal instability in microsatellite-unstable and stable colon cancer. Clin Cancer Res. 2006, 21:6379-6385.

16. Xie D, Wu HX, Liu YD, Zeng SD, Lin F. The significance and characteristics of chromosomal abnormalities in patients with microsatellite and chromosome stable colorectal carcinoma-Article in Chinese. Zhonghua Yi Xue Za Zhi. 2007, 87:11-15.

17. Yamamoto Hl, Perez-Piteira J, Yoshida T, Terada M, Itoh F, Imai $\mathrm{K}$, et al. Gastric cancers of the microsatellite mutator phenotype display characteristic genetic and clinical features. Gastroenterology. 1999, 116:1348-1357.

18. Ziadi S, Ksiaa F, Gacem RB, Labaied N, Mokni M, Trimeche M. Clinicopathologic characteristics of colorectal cancer with microsatellite instability. Pathol Res Pract. 2014, 210:98-104. 